\title{
FORMING PHYSICAL EDUCATION TEACHERS' PEDAGOGICAL MASTERY IN THE CONTEXT OF NATIVE AND FOREIGN SCHOLARS' VIEWS
}

\begin{abstract}
The article deals with studying the process of forming physical education teachers' pedagogical mastery in the context of native and foreign scholars' views. It has been indicated that the problem of pedagogical activity and pedagogical mastery efficiency has been raised in the works of a number of scholars who developed the principles and criteria of such activity. Thus, such native pedagogues as D. Dmytrenko, S. Krysyuk, I. Maslikova V. Putsov, A. Volovychenko studied the organization and evaluation of pedagogical and methodical work of teachers as well as the measuring of teaching management effectiveness. We have concluded that the forming of future physical education teachers' pedagogical mastery should include the analysis of the education content (syllabi; general, psychological and pedagogical, special subjects; their comparison and volume, etc.) and the study of future physical education teachers' personality. It is based on the use of general approaches, namely, historical, theoretical and descriptive, experimental, qualimetric (sociological) and is carried out within the diagnosis of a more general concept - a level of professional training (professional competence, the ability to obtain and generate new knowledge, to creatively solve pedagogical problems).
\end{abstract}

Key words: pedagogical mastery, knowledge, abilities, skills, professional training, physical education, physical education teacher.

\section{INTRODUCTION}

L. Korol indicates that the individual approach to professional training of future teachers (PTFT) became rather popular in the 1980s (Король, 2006). The development of a future educator as an individual and a cultured personality was studied by K. Zeichner and M. Haberman (Haberman, 1987; Zeichner, 1983). It should be mentioned that the individuality and, in particular, psychological maturity were considered to be the central aspect of professional training (Король, 2006; Онопрієнко, 2009).

A fresh perspective on the process of mastering teacher profession has become an impulse for active forming of multicultural education based on the principle of harmonious development of a personality in the diverse cultural environment. In particular, E. Bekky believes that mastering world cultural heritage should play an important place in the process of future teachers' professional training (Бэкки, 1993).

\section{THE AIM OF THE STUDY}

The aim of the article consists in studying the process of forming physical education teachers' pedagogical mastery in the context of native and foreign scholars' views.

\section{THEORETICAL FRAMEWORK AND RESEARCH METHODS}

Having compared the processes of future teachers' professional training in Ukraine and abroad during a defined period we have outlined their main similar features: orientation 
of scientific search to humanistic methodology; active theoretical understanding of the problem of teachers' professional development in higher education institutions; reforming of national systems of PTFT; higher education institutions' development and implementation of their own programmes for improving professional training of teachers (Маслікова, 2005).

The majority of scholars incline to the opinion that the methodology of research on forming future physical education teachers' pedagogical mastery should be hierarchical and consistent. It includes at least two directions that are external and internal in reference to the main subject of the educational process - a student. The first direction is the analysis of education content (syllabi; general, psychological and pedagogical, special subjects; their correspondence and volume, etc.) and the second one - the study of future physical teacher personality in the context of personal moivation, dynamics of mastering knowledge, abilities and skills, development of personal and, in particular, creative approaches to teaching, etc.

O. Onopriyenok indicates that modern native and foreign scholars agree with the statement that the category of pedagogical mastery is realized due to competency-based, activity-based and personality-based approaches as well as essential quality of pedagogical activity grounded on pedagogical knowledge, experience, wide outlook, personal culture, the ability to effectively solve complicated pedagogical tasks (Онопрієнко, 2009). Не emphasizes the synonymy of such terms as "professional readiness", "professionalism", "mastery", however, not their intercomplement nature.

It should be mentioned that since the beginning of the 1970 s the problem of pedagogical mastery has been rather widely studied abroad. For instance, special attention should be paid to researches by H. Flach, E. Loos, S. Schwanengel. They offer the summarized results of theoretical and experimental studies performed by German scientists of the 1970s, in particular, P. Ekke, F. Hofman, M. Hofman, H. Pretch, R. Pretch. Of great scientific interest are the views on the definition of pedagogical mastery, the peculiarities of its forming, structure and improvement methods (S. Arnd, E-M. Fongt, E. Furmann, G. Grassel, H-G. Hein,V. Kessel, L. Kunz, H. Lau, J. Lompscher, E. Loos, J. Rükwart, K. Scherwat, H. Zebe). Quite topical for our study are such statements:

- pedagogical mastery is an individual complex quality of teacher personality (P. Ekke), that is the subjective prerequisite for professional success (L. Kunz, J. Rükwart) and particularly reveals itself in every form of educational activity;

- structural elements of pedagogical mastery are knowledge, capabilities, practical skills and abilities (according to J. Lompscher, though, practical skills do not comprise PM) as well as volitional characteristics of personality (A. Kossakovsky, H. Zebe) (Flach, Schwanengel, 1978; Haberman, 1987).

Rather important methodological stage is the expression of structural elements of physical education teachers' pedagogical mastery. The scholars who study native and foreign experience in forming pedagogical mastery indicate that "mastery can be revealed in both standardized and atypical situations in professional activity" and consists of basic, systematic and individual knowledge.

Analyzing trends in teaching methodology in the former Soviet Union Kazakh scholars concluded that "it is impossible to provide students with the whole scope of necessary knowledge, especially professional, in the context of constantly increasing information flow". Much more important is to teach students to confidently navigate in this information, to actively obtain knowledge, to deeply analyze and elaborate it through their own imaginary actions thus forming research skills (Отегенов, Баибосынов, Габдуллин, 
2013). This suggests the topicality of the principle of openness and the relative completeness of teacher education within universities and its capacity for permanent selfeducation and monitoring the dynamics of social, political and cultural changes.

Thus, the so-called personalized pedagogical education has been actively developed in the West since the 1970s. Based on it American scholars created and tested the original model of teacher training. The mark of the author's program is the emphasis on the needs of future teachers' professional consciousness and development of their professional interests. Experimental verification of F. Fuller's program at the University of Texas proved the effectiveness of early immersion in professional activity as future educators are taught to achieve professional success and solve pedagogical tasks (Norris, 1996).

In order to study the process of forming future physical education teachers' pedagogical mastery we have used historical and empirical methods. Historical methods included historiographical (the study of historical sources), comparative and historical (the analysis of pedagogical mastery development in Ukraine and abroad), cultural and historical (the analysis of the influence of historical, cultural, political and traditional factors on the development and formation of pedagogical mastery and physical education). Empirical methods encompassed monitoring of the reference groups, analysis of results on pedagogical activity of future physical education teachers (statistical indicators of success, reports on teacher placements), sociological methods (surveys, questionnaires, testing). The inductive method has been used mainly in two aspects: the generalization of various theories of pedagogical mastery according to relevant features and the synthesis of the actual material (selection and processing valid data of reference groups).

RESULTS

The leading Polish scholars T. Lewowicki, T. Nowacki and F. Szlosek consider Ukrainian experience in forming pedagogical mastery to be a conception of training brand new teachers (Зязюн, Крамущенко, Кривонос, 2004) and highly appreciate the methodical model of forming pedagogical mastery developed in Poltava State Pedagogical Institute in the 1979-1990s (Zjaziun, Kramuszenko, Krivonos, Samieszczenko, Semiczenko, Tarasewicz, 2005). The analysis of definitions and essence of the concept of pedagogical mastery in the discourse of native and foreign scholars' views has revealed certain common ontological and existential patterns that can be generalized to the following statements:

1. Pedagogical mastery can be expressed at any lesson and at the same time it is the non-standard, creative phenomenon reflected on the background of compulsory, trivial and typical elements.

2. Students cannot be taught pedagogical mastery only by teachers, mentors or trainers. They should strive for self-education, self-discipline and self-organization.

3. Unlike competency-based knowledge, abilities and skills, needed in professional activity, pedagogical mastery is not limited to excellence and concrete description of personal qualities being a permanent process.

4. Pedagogical mastery of physical education teachers is specific and has a number of advantages over teachers of humanities and natural sciences as it is closely linked not only with cognitive, but also value-based sphere of personality and culture (axiology) and can meet the needs of spiritual, emotional and physical development.

5. Pedagogical mastery of physical education teachers is based on the acmeological (apical) goal, namely, involves real and objectively recognized results, progress, achievements, etc.

The studies of German scholars prove the prevalence of personality- and activitybased approach to the interpretation of the concept of pedagogical mastery. At the same 
time, an American scientist L. Rubin believes that pedagogical mastery includes the selection of educational goals, the use of innovative ways to achieve these goals as well as the striving for creative search, the enhancement of technical skills and the enrichment of pedagogical (Соловйов, 2013) that proves the existence of different views on the problem of pedagogical mastery in foregn literature (Zjaziun, Kramuszenko, Krivonos, Samieszczenko, Semiczenko, Tarasewicz, 2005).

An important component of pedagogical mastery which can be equated to obtaining knowledge, abilities and skills include special personal qualities, namely, combining, creativity, heuristicity, the ability to navigate in the information society and thus solve educational, psychological, epistemological and other problems and situations.

The problem of pedagogical activity and pedagogical mastery efficiency has been raised in the works of a number of scholars who developed the principles and criteria of such activity. Thus, such native pedagogues as D. Dmytrenko, S. Krysyuk, I. Maslikova V. Putsov, A. Volovychenko studied the organization and evaluation of pedagogical and methodical work of teachers as well as the measuring of teaching management effectiveness (Дмитренко, Олійник, Онуфрієва, 1996; Маслікова, 2005) Russian researchers, namely, V. Verb, N. Vodopyanova, V. Zverev considered the professional activity of teachers in terms of self-esteem, peer evaluation, relevant bodies' monitoring and instructors' observation (Зверева, 1998; Водопьянова, 1996). In the scientific discourse of foreign researchers' views the problem of teachers' professional competences effectiveness can be solved by the assessment of its socialized (integrative, managerial, interactive) functions, the familiarization with the subject as well as a block of psychological and personal qualities, namely, empathy, combining, openness, tolerance, etc. (Shulman, 1987; Norris, 1996).

I. Zyazyun suggested to assess pedagogical mastery within a more general concept - the level of professional training, including professional competence, the ability to obtain and generate new knowledge, the ability to creatively solve pedagogical tasks and problems. The scholar made a differentiation significant for our research, namely, he developed criteria for pedagogical mastery (the appropriate orientation of professional activity, the optimal selection of pedagogical tools, the dialogical essence of the interaction with students, the increase in productivity of results of educational activity and its creative nature) (Зязюн, Крамущенко, Кривонос, 2004). For the study of teachers' pedagogical mastery modern scholars use the concept of diagnostic toolset, including a range of theoretical, psychological, sociological and empirical methods. In these cases, the most important criterion is pedagogical and creative self-awareness and self-esteem that are based on the statement that a highly qualified teacher is devoted to his/her profession and has a high level of motivation. However, according to questioning of reference groups it has been found out that graduates who showed high intellectual, professional, physical and pedagogical levels in the cases of lack of motivation reveal lowered indicators while expressing the components of pedagogical mastery. This fact determined the methodological problem: pedagogical mastery of future physical education teachers requires a set of high quality indicators and the absence of even one of them has a negative influence on forming pedagogical mastery.

As for the actual pedagogical mastery of physical education teachers V. Solovyov suggests a set of criteria for teacher personality, namely, a combination of his/her physical form and athletic abilities with pedagogical tact, individuality, subjective experience and highly effective communication with students. The same can be applied to the graduates of 
the faculty of physical education (Соловйов, 2013). А. Onopriyenko proves that the development of physical education teachers' high-level pedagogical mastery precedes their mastering basic professional competencies and offers to diagnose it by: 1) setting goals and objectives of diagnosis to study the levels of basic professional competencies of future physical education teachers; 2) selecting optimal diagnostic research methods that would allow to characterize the level of formation of future physical education teachers' basic competencies; 3) collecting information through diagnostic techniques; 4) processing quantitative and qualitative results; 5) producing and formulating pedagogical forecast and trends in forming students' pedagogical mastery (Онопрієнко, 2009).

Since physical education teachers' pedagogical mastery is a hierarchical psychological formation and its level of difficulty increases in the direction from general theoretical knowledge to personal abilities, capabilities and skills, it is necessary to take a number of diagnostic measures to detect and assess the dynamics of pedagogical mastery enhancement.

The first stage of this process is theoretical and methodological diagnosis. Ideally, it consists of several successive stages: a) the clarification of the purpose and specific objectives of studying students' professional competencies; b) the selection of research methods and the inventorization of data on basic competences; c) the collection of data (the analysis of learning activities, testing, questioning); d) the processing of results (the comparison of quantitative data with optimal scale of students' professional competences at this level (the initial stage, Bachelor's degree, Master's degree); e) the evaluation of results, the forming of trends, forecasts and prospects of pedagogical mastery development, homogeneous groups, academic group of students, the learning flow, etc.

\section{CONCLUSIONS}

The forming of future physical education teachers' pedagogical mastery should include the analysis of the education content (syllabi; general, psychological and pedagogical, special subjects; their comparison and volume, etc.) and the study of future physical education teachers' personality. It is based on the use of general approaches, namely, historical, theoretical and descriptive, experimental, qualimetric (sociological) and is carried out within the diagnosis of a more general concept - a level of professional training (professional competence, the ability to obtain and generate new knowledge, to creatively solve pedagogical problems).

We believe that the further study of stages of forming future physical education teachers' pedagogical mastery will improve the professional training of future physical education teachers at native universities.

\section{REFERENCES}

1. Flach, H., Schwanengel, S. (1978). Das Wesentliche und Formierung der Pädagogischen Meisterschaft [The Essence and Forming of the Pedagogical Mastery]. Berlin : Academmie der Pädagogischen Wissenschaften DDR, 104 p. (in German).

2. Haberman, M. (1987). The Influence of Competing Cultures on Teacher Development. Perspectives of Teacher Professional Development, pp. 55-72.

3. Norris, D. (1996). Transforming Higher Education Unleashing the Power of Perpetual Learners. Proceedings of "The Virtual University" Symposium.

4. Rubin, L. J. (1985). Artistry in Teaching. New York : Random House, Inc., 176 p.

5. Shannon C., Weawer W. (1949). The Mathematical Theory of Communication. Urbana : University of Illinois Press, 389 p. 
6. Shulman, L. S. (1987). Knowledge and Teaching: Foundation of the New Reform. Harvard Educational Review, No 57 (1), pp. 1-22.

7. Sikorki, W. (1934). Wychowanie fizyczne w szkole powszechnej [Physical Education in Primary School]. Poznan : Księgarnia Św. Wojciecha, 78 p. (in Polish).

8. Zeichner, K. M. (1983). Alternative Paradigms of Education. Journal of Teacher Education, Volume XXXIV, No 3, pp. 3-9.

9. Zjaziun, I.A., Kramuszenko, L.W., Krivonos, I.F., Samieszczenko, O.G., Semiczenko, W. A., Tarasewicz, N.M. (2005). Mistrzostwo pedagogiczne [Pedagogical Championship]. Warszawa - Radom : Instytyt Technologii i Eksploatacji-PIB Radomiu, 251 p. (in Polish).

10. Бэкки, Э. (1993). Плюралистическое образование в Западной Европе на пороге нового столетия [Pluralistic Education in Western Europe at the Turn of the New Century]. Перспективы: вопросы образования [Perspectives: Issues in Education], No 2, pp. 122-128 (in Russian).

11. Водопьянова, Н. Н. (1996). Методика экспертной оценки и самооченки педагогических умений учителя [Methodology of Peer Review and Teachers' SelfAssessment of Pedagogical Skills]. Тверь : ОКУУ, 127 p. (in Russian).

12. Дмитренко, Г. А., Олійник, В. В., Онуфрієва, О. Л. (1996). Цільове управління: вимірювання результативності діяльності учнів і педагогів [Target Management: Measuring the Efficiency of Students and Teachers' Activities]. К. : УІІПКККО, 84 p. (in Ukrainian).

13. Зверева, В. И. (1998). Диагностика и экспертиза педагогической деятельности аттестуемых учителей [Diagnosis and Examination of Pedagogical Activities of Teachers under Certification]. М. : Педагогика,. 112 p. (in Russian).

14. Король, Л. Л. (2006). Розвиток педагогічної майстерності як складової професійної підготовки майбутнього вчителя в полтавському педагогічному інституті (1970-1990 рp. ХХ ст.) [The Development of Pedagogical Mastery as a Part of Future Teachers' Professional Training at Poltava Pedagogical Institute (the 1970-1990s of the 20th century)]. Thesis for $\mathrm{PhD}$. Харків, Харківський національний педагогічний університет імені Г. С. Сковороди, 235 p. (in Ukrainian).

15. Маслікова, I. (2005). Моніторингова система освітнього менеджменту [Monitoring System of Education Management]. Харків : Основа, 144 p. (in Ukrainian).

16. Онопрієнко, О. В. (2009). Формування базових компетентностей майбутнього вчителя фізичної культури у прочесі вивчення фахових дисииплін [Forming of Future Physical Education Teachers' Basic Competencies in the Process of Studying Professioanal Subjects]. Thesis for PhD. Черкаси, Черкаський національний університет імені Б. Хмельницького, 295 р. (in Ukrainian).

17. Зязюн, І. А., Крамущенко, Л. В., Кривонос, І. Ф. (2004). Педагогічна майстерність [Pedagogical Mastery]. К. : Вища школа, 422 p. (in Ukrainian).

18. Соловйов, В. (2013). Особистісно оріснтований підхід у професійній підготовці викладачів фізичного виховання [Personality-Based Approach to Professional Training of Physical Education Teachers]. Психологічні виміри культури, економіки, управління [Psychological Dimensions of Culture, Economy, Management], No 1, pp. 135-141 (in Ukrainian).

19. Отегенов, Н. О., Баибосынов, С. Ж., Габдуллин, А. Б. (2013). Проблема повышения качества подготовки специалистов физической культуры и спорта [The Problem of Enhancing the Quality of Physical Education Specialists]. Теория и методика физической культуры [Theory and Methodology of Physical Culture], No 1 (32), pp. 13-15 (in Russian). 